\title{
Evaluation of liver injury in a tertiary hospital: a retrospective study
}

\author{
İsmail Bilgiç, M.D., ${ }^{1}$ Sibel Gelecek, M.D., ${ }^{1}$ Ali Emre Akgün, M.D., ${ }^{1}$ Mehmet Mahir Özmen, M.D. ${ }^{2}$
}

${ }^{1}$ Department of General Surgery, Ankara Numune Training and Research Hospital, Ankara;

${ }^{2}$ Department of General Surgery, Hacettepe University Faculty of Medicine, Ankara

\begin{abstract}
BACKGROUND: Liver is the most frequently injured intraabdominal organ following abdominal trauma. Liver injury in polytraumatized patients can vary from minor contusions to major lacerations and is associated with morbidity and mortality. The objective of this study was to evaluate the outcome of liver injury in polytraumatized patients.
\end{abstract}

METHODS: Only surgically treated 82 patients with liver injury over an eight year period (2005-20I3) were included in this study and analyzed retrospectively. Data collected included demographics, laboratory findings, intraoperative findings, operative management, and outcome. The patients were divided into two groups and the mortality and survival data were compared.

RESULTS: The overall mortality rate was $18.3 \%$ (I5 of 82 patients). 34 (4I.5\%) patients had blunt, forty-eight (48.5\%) had penetrating trauma. There were multiple traumas in forty-seven (57\%) patients. Forty-seven (57\%) patients had total of seventy one coexisting intraabdominal injuries. Forty-six (56.1\%) patients had stable and thirty-six (43.9\%) had unstable hemodynamics on admission. In mortality group AST, ALT, LDH, APTT, PT, INR, and creatinine levels were high, fibrinogen levels and platelet counts were low on admission.

CONCLUSION: Hemodynamic instability, coexisting musculoskeletal and chest injury, high APTT, PT, INR, AST, ALT, LDH levels, and low fibrinogen levels and platelet counts on admission should be considered as predictive factors for mortality.

Key words: Liver enzymes; liver injury; mortality.

\section{INTRODUCTION}

Liver is the most frequently injured organ following abdominal trauma ${ }^{[1]}$ and associated injuries contribute significantly to morbidity and mortality. Liver is a particularly vulnerable organ because of its size and the fixed position in the right hypochondria. Mortality rates have fallen from $66 \%$ in World War II to current levels of $28 \%$;[2,3] however, mortality rates from complex liver trauma still remain high despite improvements in resuscitation, anesthesia and intensive care facilities. ${ }^{[4]}$

The aim of this retrospective study was to document the outcome of the patients treated operatively.

Address for correspondence: İsmail Bilgiç, M.D.

Ülkü Mah., Talatpaşa Bulvarı, No: 5, Altındağ, 06100 Ankara, Turkey

Tel: +90 312 - 5085133 E-mail: drismailbilgic@gmail.com

Qucik Response Code Ulus Travma Acil Cerrahi Derg

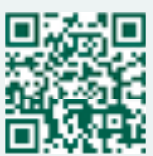

20।4;20(5):359-365

doi: $10.5505 /$ tjtes.20I4.22074

Copyright 2014

TJTES

\section{MATERIALS AND METHODS}

This retrospective clinical study was performed in the Emergency Service of Ankara Numune Teaching and Research Hospital between August 2005 and January 2013. Only surgically treated 82 patients were included in this study and analyzed. All patients had either unstable hemodynamics or signs of abdominal injuries requiring operation. Clinical data regarding patient demographics, AST (aspartate aminotransferase), ALT (alanine aminotransferase), LDH (lactate dehydrogenase), APTT (activated partial thromboplastin time), PT (prothrombin time), INR (international normalized ratio), fibrinogen, urea, creatinine, hemoglobin levels, platelet counts, and white blood cell counts on admission, mechanism of injury, hemodynamic status on presentation, hepatic injury grade, operative procedures, coexisting abdominal and extraabdominal injuries, number of blood transfusion, outcome in terms of liver injury related morbidity and mortality were collected. Coexisting extra-abdominal injuries were divided broadly into cranial injury, chest injury (including rib fracture, haemothorax or pneumothorax, lung and cardiac), musculoskeletal system injuries (including long bone fracture) and retroperitoneal hematoma (including pelvic fracture and great vessel injury). 
In accordance with the current Advanced Trauma Life Support (ATLS) protocols, patients were divided into two main groups according to the hemodynamics at presentation: stable and unstable. ${ }^{[5]}$ Hemodynamic instability was defined as systolic blood pressure less than $90 \mathrm{mmHg}$ and pulse rate higher than 100 beats per minute at the time of presentation in our hospital. Three patients were in cardiopulmonary arrest on admission and were operated soon after resuscitation. Those patients were classified in a third group called "cardiopulmonary arrest".

Based on the operation record, liver injuries were graded according to the Organ Injury Scale of the American Association for the Surgery of Trauma. ${ }^{[6]}$ The surgical techniques used to control bleeding during the operations were grouped into five categories including non-therapeutic, simple hemostatic measures, hepatorrhaphy with primary saturation, segmentectomy and lobectomy. Intervention was considered non-therapeutic when no active bleeding from the liver injury was detected. Superficial lacerations were managed by simple hemostatic measures such as diathermy and application of biomaterials (collagen sponge, oxidized regenerated cellulose gauze). Hepatorrhaphy was performed applying deep horizontal mattress stitches with polyglycolic acid. Peripherally located large lacerated segments were resected in non-anatomical fashion. Lobectomy was carried out as right hepatectomy in anatomical fashion.

\section{Statistical Method}

Data were analyzed using the statistical package, PASW 18.0 for Windows (SPSS, Chicago, IL, USA). The KolmogorovSmirnov test was applied to evaluate the distribution of values in continuous variables. The chi-squared test or Fischer's exact test was used to compare categorical data. For the parametric distribution, Student's t-test was used to compare the mean values of two groups. For nonparametric variables, the Kruskal-Wallis test or Mann-Whitney U-test was used to compare the median values of the response variable. Correlation analysis was performed using Pearson or Spearman. A stepwise logistic regression analysis was also carried out. The model included explanatory or predictive factors as variables suggested in the univariate analysis to be more strongly and significantly associated with mortality. Mortality was the outcome variable for multivariate analysis. The odds ratio (OR) was calculated as an estimate of relative risk between two groups on the basis of mortality as an outcome. Statistical significance was defined as $p<0.05$.

\section{RESULTS}

From August 2005 to January 2013, 82 patients with liver trauma were surgically treated in the Department of Emergency Service of Ankara Numune Teaching and Research Hospital. Among these eighty-two patients, there were 77 (94\%) males and $5(6 \%)$ females, with a mean age of 34 years (range, 17-
90) (Table I). The overall mortality rate was I8.3\%. Patients' white blood cell count (WBC), platelet count, hemoglobin, AST, ALT, LDH, APTT, PT, INR, fibrinogen, urea and creatinine levels were measured on admission (Table I). Age had no significant effect on mortality $(p=.08)$; however, the female gender was found to be significant on mortality $(p=.04)$.

Injury was defined as blunt trauma in thirty-four (41.5\%) patients, stab wounds in thirty-eight (46.3\%) and gunshot injury in ten (12.2\%) patients. Forty-six (56.1\%) patients had stable, thirty-three (40.2\%) had unstable hemodynamics and three (3.7\%) were in cardiopulmonary arrest on admission. Considering the intraabdominal injury; 35 patients had isolated liver injury and the remaining forty-seven (57\%) had a total of seventy one coexisting intraabdominal injuries. Liver injury occurred as a component of multiple traumas in forty-seven (57\%) patients. Musculoskeletal system injuries were the most common coexisting injuries (Table 2).

In operative findings, according to the Organ Injury Scale of the American Association for the Surgery of Trauma, 27 (33\%) patients had Grade I, thirty-seven (45\%) had Grade II, fifteen (18\%) had Grade III, two (3\%) had Grade IV and one (I\%) had Grade $V$ injuries (Table 2). No active bleeding from the liver in $10(12 \%)$ patients undergoing non-therapeutic intervention during surgery was detected. Simple hemostatic measures such as diathermy, application of biomaterials (collagen sponge, oxidized regenerated cellulose gauze) were performed in fifteen (18\%) patients. Hepatorrhaphy was the most common surgical procedure employed to control the bleeding in fifty-four (66\%) patients. Two patients (3\%) had peripherally located large lacerated segments and non-anatomical segmental resections were performed. A patient had central crush

Table I. Laboratory findings

\begin{tabular}{lc}
\hline Parameter & Mean \pm SD \\
\hline Age (year) & $34.0 \pm 13.4$ \\
Hemoglobin (gr/dl) & $13.1 \pm 2.3$ \\
White blood cells & $14784.4 \pm 6940.3$ \\
Platelet (/mm $\left.{ }^{3}\right)$ & $246500 \pm 78200$ \\
Urea levels & $34.07 \pm 19.7$ \\
Creatinine levels & $1.08 \pm .44$ \\
Aspartate aminotransferase & $277.6 \pm 382.4$ \\
Alanine aminotransferase & $272.9 \pm 394.02$ \\
Lactate dehydrogenase & $648.4 \pm 624.4$ \\
Activated partial thromboplastin time & $33.2 \pm 3.7$ \\
Prothrombin time & $16.4 \pm 1.0$ \\
International normalized ratio & $1.3 \pm .08$ \\
Fibrinogen & $195.6 \pm 89.5$ \\
Transfusion requirement & $2.3 \pm 3.8(0-16)$ \\
\hline
\end{tabular}


Table 2. Clinical features

\begin{tabular}{|c|c|c|}
\hline & $\mathbf{n}$ & $\%$ \\
\hline \multicolumn{3}{|l|}{ Type of injury } \\
\hline Blunt trauma & 34 & 41.5 \\
\hline Stab wounds & 38 & 46.3 \\
\hline Gunshot wounds & 10 & 12.2 \\
\hline \multicolumn{3}{|l|}{ Hemodynamic status on admission } \\
\hline Cardiopulmonary arrest & 3 & 3.7 \\
\hline Unstable & 33 & 40.2 \\
\hline Stable & 46 & 56.1 \\
\hline \multicolumn{3}{|l|}{ Grade of liver injury } \\
\hline Grade I & 27 & 33 \\
\hline Grade II & 37 & 45 \\
\hline Grade III & 15 & 19 \\
\hline Grade IV & 2 & 2 \\
\hline Grade V & I & 1 \\
\hline \multicolumn{3}{|l|}{ Operative procedure } \\
\hline Non-therapeutic & 10 & 12 \\
\hline Simple hemostatic measures & 15 & 18 \\
\hline Hepatorrhaphy & 54 & 66 \\
\hline Segmentectomy & 2 & 3 \\
\hline Lobectomy & $\mathrm{I}$ & 1 \\
\hline \multicolumn{3}{|l|}{ Coexisting intraabdominal injury } \\
\hline Diaphragm & 18 & 25 \\
\hline Spleen & 13 & 18 \\
\hline Stomach & II & 16 \\
\hline Kidney & 8 & II \\
\hline Colon & 7 & 10 \\
\hline Small intestine & 5 & 7 \\
\hline Duodenum & 4 & 6 \\
\hline Gallbladder & 4 & 6 \\
\hline Pancreas & 1 & 1 \\
\hline \multicolumn{3}{|l|}{ Coexisting extra-abdominal injury } \\
\hline Musculoskeletal system & 24 & 35 \\
\hline Chest trauma & 22 & 32 \\
\hline Retroperitoneal injury & 16 & 23 \\
\hline Cranial injury & 7 & 10 \\
\hline
\end{tabular}

injury resulting in a stellate-type laceration including segment $5,6,7,8$ and right hepatic vein injury in the liver. Right hepatectomy was performed for this patient (Table 2).

High levels of AST, ALT, LDH, APTT, PT, INR, creatinine and low levels of fibrinogen and low platelet counts on admission were found to be associated with mortality (Table 3). In addition, AST, ALT, APTT, PT, INR, and LDH levels on admission were found to be correlated with the grade of liver injury (Table 4). LDH levels on admission were found as an independent risk factor for mortality in multivariate analysis $(p=0.008)$. Preoperative blood transfusion requirement ranged from $0-16$ units (mean: $2.3 \pm 3.8$ ) and it was statistically correlated with the grade of liver injury $(p=0.003)$ (Table 4$)$.

Hemodynamic instability on admission and the type of injury were found to be significantly correlated with mortality $(p=.00 \mathrm{I}$ and $p=.04$, respectively) (Table 5).

Accompanying abdominal injuries were not observed to be associated with mortality; however, the grade of the liver injury, presence of musculoskeletal system and chest injury were found to be associated with mortality (Table 5).

Packing was performed in 6 patients. In those patients, three had grade III and two had grade IV and one had grade $V$ injuries. Among the two patients who died in the packing group, one had grade IV and the other had grade III injuries. A significant relationship between the grade of the liver injury and packing application was observed (Table 4).

Out of 82 patients, fifteen did not survive. Two of them had isolated liver injury and both injuries were caused by blunt trauma. The mean age in the mortality group was 35 (range, 20-6I) years. Among the fifteen patients, 12 (80\%) were males and $3(20 \%)$ were females. Ten $(66.7 \%)$ patients had blunt trauma, 3 (20\%) had stab wounds and 2 (13.3\%) had gunshot wounds. One (6.7\%) patient was in cardiopulmonary arrest, 2 (I3.3\%) were hemodynamically stable and I 2 (80\%) were hemodynamically unstable on admission. The grade of the liver injury, applied surgical technique and laboratory results were shown on Table 6.

Eight patients $(9.75 \%)$ required re-laparotomy for various reasons including the removal of packs (3), no improvement (2), and intra-abdominal abscess formation (2). There was only one bile leak treated non-operatively.

\section{DISCUSSION}

Although splenic injuries are more common following blunt abdominal trauma, liver is the most frequently injured intraabdominal organ. ${ }^{[4]}$ Complex liver injuries are still a challenging problem with high mortality rates (50\%) despite improvements in resuscitation, surgical skills, anesthesia and intensive care. High grade liver injuries are usually associated with extra and intra-abdominal injuries due to high magnitude of the trauma, increasing the rate of mortality. The aim of this retrospective research was to evaluate the outcomes of surgically treated patients.

Seventy seven (94\%) patients were male in our study. A male predominance has been demonstrated in almost every other liver trauma series, including studies from England (79\%), ${ }^{[7]}$ other parts of Western Europe (67\%-74\%), ${ }^{[8-10]}$ South Africa 
Table 3. Significant laboratory findings for mortality

\begin{tabular}{lccc}
\hline & Mortality group & Survival group & p \\
\hline Age & $34.8( \pm I I .5)$ & $33.8( \pm 13.8)$ & .08 \\
Hemoglobin & $12.2( \pm 2.8)$ & $13.3( \pm 2.1)$ & .117 \\
White blood cells & $18046( \pm 8687)$ & $14111( \pm 6400)$ & .062 \\
Platelet & $205000( \pm 76000)$ & $257000( \pm 75000)$ & .025 \\
Urea & $40.54( \pm 41.75)$ & $32.65( \pm 10.16)$ & .193 \\
Creatinine & $1.4( \pm .75)$ & $1.0( \pm .3)$ & .003 \\
Aspartate aminotransferase & $559.2( \pm 462.2)$ & $217.3( \pm 338.2)$ & .001 \\
Alanine aminotransferase & $546.0( \pm 495.6)$ & $215.4( \pm 347.7)$ & .001 \\
Lactate dehydrogenase & $1378( \pm 775.4)$ & $533.2( \pm 521.5)$ & .009 \\
Activated partial thromboplastin time & $40.2(23.8-133)$ & $23.6(17.5-51.9)$ & .000 \\
Prothrombin time & $20(12.7-47)$ & $13.8(12-19)$ & .004 \\
International normalized ratio & $1.56(1.02-3.75)$ & $1.1(.95-1.68)$ & .004 \\
Fibrinogen & $129.2( \pm 56)$ & $219.7( \pm 85.77)$ & .002 \\
\hline
\end{tabular}

Table 4. Factors correlated with the grade of the liver injury

\begin{tabular}{lcc}
\hline & \multicolumn{2}{c}{ Grade of the liver injury } \\
\cline { 2 - 3 } & $\mathbf{r}$ & $\mathbf{p}$ \\
\hline Aspartate aminotransferase & .346 & 0.004 \\
Alanine aminotransferase & .324 & 0.007 \\
Lactate dehydrogenase & .561 & $<0.001$ \\
Activated partial thromboplastin time & .30 & 0.046 \\
Prothrombin time & .36 & 0.019 \\
International normalized ratio & .36 & 0.02 \\
Blood transfusion requirement & .322 & 0.003 \\
Packing & .352 & 0.001 \\
\hline
\end{tabular}

$(81 \%)^{[11]}$ and North America (61\%- 79\%). ${ }^{[12]}$ Although the female gender was found to have a statistically significant effect on mortality, no homogeneity in gender distribution could be observed in our study as there were only five female patients. A higher frequency of liver trauma among younger patients was determined in the present study. Wilson et al. ${ }^{[13]}$ have reviewed many series of liver trauma and emphasized that the patient average age tended to lie between 25 and 30. Continuity of this global pattern has been shown in more recent works. Large liver trauma series have shown mean ages of 35 , 32 , and 30, respectively in Germany, ${ }^{[10]}$ South Africa, ${ }^{\left[{ }^{11]}\right.}$ and North America. ${ }^{[12]}$

In the present study, liver injuries were caused by blunt trau$\mathrm{ma}$ in $41.5 \%$ of the patients ( $12.2 \%$ falls from height, $29.3 \%$ road traffic accidents) and penetrating trauma was seen in $58.5 \%$ of the patients ( $46.3 \%$ stab wounds, $12.2 \%$ gunshot wounds). Scollay et al. ${ }^{[14]}$ have shown that European authors have reported high frequencies of blunt trauma. On the contrary, Krige, ${ }^{\left[{ }^{\prime \prime}\right]}$ reporting the South African experience, found that $66 \%$ of 446 patients had sustained penetrating liver injury. Feliciano et al. ${ }^{[15]}$ have reviewed 1000 patients with liver trauma and found that penetrating trauma was responsible for $86 \%$ of hepatic injuries. On the other hand, incidence of stab wounds in penetrating trauma in the present study was similar to the European series having significantly higher incidence of stab injuries and a lower incidence of gunshot wounds. ${ }^{[14]}$ It has also been shown that blunt injuries have consistently been associated with a higher mortality rate than penetrating injuries. ${ }^{[16,17]}$ In the present study, mortality has been found to be significantly higher in blunt trauma patients. This might partly be explained by blunt traumas being usually associated with extra and intra-abdominal injuries increasing mortality rates due to the high magnitude of trauma. 
Table 5. Gender, coexisting extra-abdominal and intra-abdominal injuries and hemodynamic status

\begin{tabular}{|c|c|c|c|c|c|}
\hline & \multicolumn{2}{|c|}{ Mortality group } & \multicolumn{2}{|c|}{ Survivor group } & \multirow[t]{2}{*}{$\mathbf{p}$} \\
\hline & $\mathbf{n}$ & $\%$ & $\mathbf{n}$ & $\%$ & \\
\hline Female (Gender) & 3 & 20 & 2 & 3 & .04 \\
\hline Type of trauma (Blunt/penetrant) & $10 / 5$ & $29 / 10$ & $24 / 43$ & $71 / 90$ & .04 \\
\hline Musculoskeletal system & 8 & 33.3 & 16 & 66.7 & .03 \\
\hline Chest trauma & 8 & 36.4 & 14 & 63.6 & .02 \\
\hline Retroperitoneal injury & 4 & 25 & 12 & 75 & .5 \\
\hline Cranial injury & 3 & 42.9 & 4 & 57.1 & .1 \\
\hline Diaphragm & 4 & 22.2 & 14 & 77.8 & .7 \\
\hline Spleen & 4 & 30.8 & 9 & 69.2 & .2 \\
\hline Stomach & 2 & 18.2 & 9 & 81.8 & 1.0 \\
\hline Kidney & I & 12.5 & 7 & 87.5 & 1.0 \\
\hline Colon & 3 & 42.9 & 4 & 57.1 & .1 \\
\hline Hemodynamic instability & 12 & 48 & 21 & 31 & .001 \\
\hline
\end{tabular}

In the present study, hemodynamic instability was recorded in $40 \%$ of liver trauma patients. These patients had a higher mortality rate than those who had a blood pressure higher than $90 \mathrm{mmHg}(p=0.00 \mathrm{I})$. Several studies have identified hemodynamic instability as an early predictor of outcome after severe injuries. ${ }^{[4,9,14,18-21]}$ It has been shown by Clarke et al. ${ }^{[22]}$ that mortality increases by $1 \%$ every 3 minutes after a trauma involving hematogenic shock. Also, Wilson have emphasized that shock on admission is thought to double the mortality rates. ${ }^{[23]}$ High mortality rates due to hemodynamic instability may be the result of severe exsanguinating hemorrhage resulting in catastrophic final pathway of hypothermia, coagulation, and acidosis.

Table 6. Demographic and clinical features of the mortality group

\begin{tabular}{lll}
\hline & n & $\%$ \\
\hline Grade of liver injury & & \\
Grade I & I & 6.7 \\
Grade II & 6 & 40 \\
Grade III & 6 & 40 \\
Grade IV & I & 6.7 \\
Grade V & I & 6.7 \\
Operative procedure & & \\
Non-therapeutic & 3 & 20 \\
Simple hemostatic measures & I & 6.7 \\
Hepatorrhaphy & 9 & 60 \\
Segmentectomy & I & 6.7 \\
Lobectomy & I & 6.7 \\
\hline
\end{tabular}

Hemorrhage accounts for over the third of early trauma deaths $^{[24]}$ and is a leading cause of preventable mortality. ${ }^{[25]}$ Acute traumatic coagulopathy is known to occur in about $28 \%$ to $34 \%$ of patients with multiple injuries. ${ }^{[26]}$ Most of the literature characterizes the condition by reference to an elevated INR, PT and/or PTT of 1.5 or 2 times normal. ${ }^{[27]}$ It has been shown in many studies that patients arriving in the emergency department with a coagulopathy are three to four times more likely to die and eight times more likely to die within the first 24 hours. ${ }^{[26,28,29]}$ In the present study, we found that PT, APTT and INR were significantly high in the mortality group than in the survivors. There are controversies about fibrinogen levels in acute traumatic coagulopathy. Martini et al. ${ }^{[30]}$ have shown that fibrinogen levels rarely decrease in patients with acute traumatic coagulopathy. On the other hand, it has been shown that fibrinogen concentrations rapidly decline after injury especially in hypoperfusion. ${ }^{[31]}$ Significantly low fibrinogen levels were detected in the mortality group. Platelet counts are mildly reduced by trauma and this appears to be associated with poor outcomes. ${ }^{[31]}$ Brown et al. ${ }^{[32]}$ have reported that platelet count on admission is inversely correlated with 24-hour mortality. In the present study, low platelet counts were significantly correlated with mortality. All these parameters are important since recent therapeutic and observational studies have demonstrated improved survival rates with better and early management of hemostasis after injury. ${ }^{[31]}$ Additionally, early identification of the need for massive transfusion (MT) may increase the speed and success of hemostatic intervention in trauma patients. The use of massive transfusion protocols standardizing blood component therapy that automatically delivers at specific points within resuscitation may be of benefit to prevent and treat early coagulopathy. 
It is well-known that liver injuries almost always accompany injuries to other organ systems and liver injury has been found to be associated with high mortality rates with the presence of coexisting injuries. ${ }^{[33,34]}$ Also, Nishida et al. ${ }^{[18]}$ have founded that the presence of a coexisting injury is an independent prognostic factor for mortality in their multivariate analysis. In the present study, the presence of musculoskeletal injury and chest injury were both found to be associated with high mortality rates $(p=.03$ and $p=.02)$.

Elevated serum liver enzymes, AST and ALT, are known to be associated with blunt traumatic liver injury. It has been shown in animal models and human studies that not only does the increase in the enzyme occur within a few hours after blunt liver trauma, but the amount of the increase in the enzyme also correlates to the severity of liver injury, as in the present study. ${ }^{[35]}$ Similarly, statistically significant and increasing ALT levels were observed among patients with increasing grades of liver injury. ${ }^{[7]}$ Tan et al. ${ }^{[21]}$ have reported that there is an important relationship between ALT, AST and hepatic injuries after blunt abdominal trauma and also patients with normal ALT, AST and LDH are unlikely to have major liver injury. Nishida et al. ${ }^{[18]}$ have shown that ALT is an independent risk factor for mortality in their multivariate analysis. AST and ALT levels on admission were found to be correlated with mortality and severity of liver injury in the present study.

LDH is a cytoplasmic enzyme present essentially in all major organ systems. The extracellular appearance of LDH is used to detect cell damage or cell death. It is released into the peripheral blood after cell death caused by ischemia, excess heat or cold, starvation, dehydration, injury, exposure to bacterial toxins, ingestion of certain drugs, and chemical poisonings. Due to its extraordinarily widespread distribution in the body, the total serum LDH is a highly sensitive, but nonspecific test. In the present study, LDH levels on admission were found to be correlated with mortality and severity of the liver injury; in addition, LDH was found as an independent risk factor for mortality in multivariate analysis in the present study. High LDH levels may reflect the number and severity of effected organs. AST, ALT and LDH together may be useful for prognostic factors in liver injury.

\section{Conclusion}

Hemodynamic instability, coexisting musculoskeletal and chest injury, and high APTT, PT, INR, AST, ALT, LDH levels and low fibrinogen levels and low platelet counts on admission should be considered as predictive factors for mortality in patients who sustained liver injury due to trauma. It is crucial to keep in mind that the high AST, ALT and LDH levels on admission might also reflect the high grade of liver injury.

Conflict of interest: None declared.

\section{REFERENCES}

1. Feliciano DV. Surgery for liver trauma. Surg Clin North Am 1989;69:273-84.

2. Richardson JD. Changes in the management of injuries to the liver and spleen. J Am Coll Surg 2005;200:648-69. CrossRef

3. Trunkey DD. Hepatic trauma: contemporary management. Surg Clin North Am 2004;84:437-50. CrossRef

4. Parks RW, Chrysos E, Diamond T. Management of liver trauma. Br J Surg 1999;86:1121-35. CrossRef

5. American College of Surgeons Committee on Trauma. Advanced Trauma Life Support Student Manuel. 5th ed. Chicago, Illionis: American College of Surgeons; 1995.

6. Moore EE, Cogbill TH, Jurkovich GJ, Shackford SR, Malangoni MA, Champion HR. Organ injury scaling: spleen and liver (1994 revision). J Trauma 1995;38:323-4. CrossRef

7. John TG, Greig JD, Johnstone AJ, Garden OJ. Liver trauma: a 10-year experience. Br J Surg 1992;79:1352-6. CrossRef

8. Talving P, Beckman M, Häggmark T, Iselius L. Epidemiology of liver injuries. Scand J Surg 2003;92:192-4.

9. Menegaux F, Langlois P, Chigot JP. Severe blunt trauma of the liver: study of mortality factors. J Trauma 1993;35:865-9. CrossRef

10. Matthes G, Stengel D, Seifert J, Rademacher G, Mutze S, Ekkernkamp A. Blunt liver injuries in polytrauma: results from a cohort study with the regular use of whole-body helical computed tomography. World J Surg 2003;27:1124-30. CrossRef

11. Krige JE, Bornman PC, Terblanche J. Liver trauma in 446 patients. S Afr J Surg 1997;35:10-5.

12. Pachter HL, Knudson MM, Esrig B, Ross S, Hoyt D, Cogbill T, et al. Status of nonoperative management of blunt hepatic injuries in 1995: a multicenter experience with 404 patients. J Trauma 1996;40:31-8. CrossRef

13. Wilson RH, Moorehead RJ. Hepatic trauma and its management. Injury 1991;22:439-45. CrossRef

14. Scollay JM, Beard D, Smith R, McKeown D, Garden OJ, Parks R. Eleven years of liver trauma: the Scottish experience. World J Surg 2005;29:7449. CrossRef

15. Feliciano DV, Mattox KL, Jordan GL Jr, Burch JM, Bitondo CG, Cruse PA. Management of 1000 consecutive cases of hepatic trauma (1979. 1984). Ann Surg 1986;204:438-45. CrossRef

16. Fabian TC, Croce MA, Stanford GG, Payne LW, Mangiante EC, Voeller GR, et al. Factors affecting morbidity following hepatic trauma. A prospective analysis of 482 injuries. Ann Surg 1991;213:540-8. CrossRef

17. Rivkind AI, Siegel JH, Dunham CM. Patterns of organ injury in blunt hepatic trauma and their significance for management and outcome. J Trauma 1989;29:1398-415. CrossRef

18. Nishida T, Fujita N, Nakao K. A multivariate analysis of the prognostic factors in severe liver trauma. Surg Today 1996;26:389-94. CrossRef

19. Sikhondze WL, Madiba TE, Naidoo NM, Muckart DJ. Predictors of outcome in patients requiring surgery for liver trauma. Injury 2007;38:65-70.

20. Velasco RA, Martínez FB, Fernández GB, Peck GS. Management of hepatic trauma: four years experience. [Article in Spanish] Cir Esp 2011;89:511-6. [Abstract]

21. Tan KK, Bang SL, Vijayan A, Chiu MT. Hepatic enzymes have a role in the diagnosis of hepatic injury after blunt abdominal trauma. Injury 2009;40:978-83. CrossRef

22. Clarke JR, Trooskin SZ, Doshi PJ, Greenwald L, Mode CJ. Time to laparotomy for intra-abdominal bleeding from trauma does affect survival for delays up to 90 minutes. J Trauma 2002;52:420-5. CrossRef 
23. Wilson RH, Moorehead RJ. Hepatic trauma and its management. Injury 1991;22:439-45. CrossRef

24. Sauaia A, Moore FA, Moore EE, Moser KS, Brennan R, Read RA, et al. Epidemiology of trauma deaths: a reassessment. J Trauma 1995;38:18593. CrossRef

25. Gruen RL, Jurkovich GJ, McIntyre LK, Foy HM, Maier RV. Patterns of errors contributing to trauma mortality: lessons learned from 2,594 deaths. Ann Surg 2006;244:371-80.

26. Brohi K, Cohen MJ, Ganter MT, Matthay MA, Mackersie RC, Pittet JF. Acute traumatic coagulopathy: initiated by hypoperfusion: modulated through the protein C pathway? Ann Surg 2007;245:812-8. CrossRef

27. Cosgriff N, Moore EE, Sauaia A, Kenny-Moynihan M, Burch JM, Galloway B. Predicting life-threatening coagulopathy in the massively transfused trauma patient: hypothermia and acidoses revisited. J Trauma 1997;42:857-62. CrossRef

28. Brohi K, Singh J, Heron M, Coats T. Acute traumatic coagulopathy. J Trauma 2003;54:1127-30. CrossRef

29. MacLeod JB, Lynn M, McKenney MG, Cohn SM, Murtha M. Early coagulopathy predicts mortality in trauma. J Trauma 2003;55:39-44.
30. Martini WZ, Dubick MA, Pusateri AE, Park MS, Ryan KL, Holcomb JB. Does bicarbonate correct coagulation function impaired by acidosis in swine? J Trauma 2006;61:99-106. CrossRef

31. Frith D, Davenport R, Brohi K. Acute traumatic coagulopathy. Curr Opin Anaesthesiol 2012;25:229-34. CrossRef

32. Brown LM, Call MS, Margaret Knudson M, Cohen MJ. (Trauma Outcomes Group). A normal platelet count may not be enough: the impact of admission platelet count on mortality and transfusion in severely injured trauma patients. J Trauma 2011;71(2 Suppl 3):337-42. CrossRef

33. Croce MA, Fabian TC, Menke PG, Waddle-Smith L, Minard G, Kudsk $\mathrm{KA}$, et al. Nonoperative management of blunt hepatic trauma is the treatment of choice for hemodynamically stable patients. Results of a prospective trial. Ann Surg 1995;221:744-55. CrossRef

34. Domínguez Fernández E, Aufmkolk M, Schmidt U, Nimtz K, Stöblen $\mathrm{F}$, Obertacke $\mathrm{U}$, et al. Outcome and management of blunt liver injuries in multiple trauma patients. Langenbecks Arch Surg 1999;384:453-60.

35. Ritchie AH, Williscroft DM. Elevated liver enzymes as a predictor of liver injury in stable blunt abdominal trauma patients: case report and systematic review of the literature. Can J Rural Med 2006;11:283-7.

\section{KLINIIK ÇALIŞMA - ÖZET}

\section{Üçüncü basamak hastanede karaciğer travmalarının değerlendirilmesi: Geriye dönük bir çalışma \\ Dr. İsmail Bilgiç, ${ }^{1}$ Dr. Sibel Gelecek, ${ }^{1}$ Dr. Ali Emre Akgün, ${ }^{1}$ Dr. Mehmet Mahir Özmen ${ }^{2}$}

${ }^{1}$ Ankara Numune Eğitim ve Araştırma Hastanesi, Genel Cerrahi Kliniği, Ankara;
${ }^{2}$ Hacettepe Üniversitesi Tıp Fakültesi, Genel Cerrahi Kliniği, Ankara

AMAÇ: Abdominal travmalarda karaciğer en sık yaralanan organdır. Politravmatik bir hastada karaciğer yaralanması minör yaralanmalardan majör yaralanmalara kadar değişen bir şekilde etkilenebilir. Bu yaralanma derecesine göre morbidite ve mortaliteye katkıda bulunur. Bu çalışmanın amacı ameliyatta karaciğer yaralanması tespit edilen hastaların sonuçlarının değerlendirilmesidir.

GEREÇ VE YÖNTEM: 2005 ve 2013 yılları arasında, sadece cerrahi sırasında karaciğer hasarı tespit edilen 82 hasta geriye dönük olarak incelendi. Hastaların demografik verileri, laboratuvar verileri, ameliyat bulguları ve yapılan ameliyatları incelendi. Hastalar iki gruba ayrıldı: Mortalite grubu ve yaşayan hastalar grubu.

BULGULAR: Çalışmadaki erkek hasta sayısı 77 (\%94), kadın hasta sayısı beş (\%6) olarak bulundu. Ortalama yaş 34 (I7-90) idi; I5 (\%।8.3) hastada mortalite gözlendi, 34 (\%4I.5) hastada künt karın travması, 48 (\%48.5) hastada penetran yaralanma mevcuttu. Hastaların 47'sinde (\%57) çoklu travma mevcuttu, 47 (\%57) hastada 7 I adet eşlik eden karıniçi diğer organ yaralanmaları mevcuttu. Başvuru anında hemodinamik olarak 46 (\%56.I) hasta stabil, 36 (\%43.9) hasta unstabil idi. Başvuru anındaki AST, ALT, LDH, APTT, PT, INR ve kreatinin değerleri mortalite grubunda yaşayan hasta grubuna göre daha yüksek, fibrinojen ve trombosit sayısı ise daha düşük idi.

TARTIŞMA: Hemodinamik instabilite, eşlik eden iskelet sistemi göğüs travması, başvuru anındaki yüksek APTT, PT, INR, AST, ALT, LDH ve düşük fibrinojen ve trombosit değerleri mortalite açısından prognostik faktörler olabilir.

Anahtar sözcükler: Karaciğer enzimleri; karaciğer hasarı; mortalite.

Ulus Travma Acil Cerrahi Derg 2014;20(5):359-365 doi: 10.5505/tjtes.20I4.22074 